Niniejsza publikacja jest dostępna na licencji Creative Commons. Uznanie autorstwa-Użycie niekomercyjne-Bez utworów zależnych 3.0 Polska. Pewne prawa zastrzeżone na rzecz autora. Zezwala się na wykorzystanie publikacji zgodnie z licencja - pod warunkiem zachowania niniejszej informacji licencyjnej oraz wskazania autora jako właściciela praw do tekstu. Treść licencji jest dostępna na stronie: http://creativecommons.org/licenses/by-nc-nd/3.0/pl/

Lingwistyka Stosowana 16: 1/2016, 87-93

\author{
Anna SZAFERNAKIER-ŚWIRKO \\ Uniwersytet Warszawski
}

\title{
Nauczanie dorosłych - nowe wyzwania. (Na przykładzie indywidualnych zajęć języka rosyjskiego z klientem biznesowym)
}

\begin{abstract}
:
Teaching adults - new challenges (the case of Russian language classes with an individual business client)

In the article the issue of teaching the foreign language to adult learners has been raised. The author presented a set of components allowing to conduct individual foreign language classes with a business client effectively. Special attention has been paid to non-linguistic elements of a didactic unit which allow to diversify the classes and which introduce friendly atmosphere that simplifies the memorization of the material. The opinion has been stated that the key to effective teaching and educational success is the attitude of a teacher who builds a creative and dynamic team together with a student. As a conclusion the author presented a few rules of good foreign language classes in business environment .
\end{abstract}

\section{Wstęp}

Nauczanie dorosłych jest niewątpliwie ważnym aspektem współczesnej metodyki. Osoby dorosłe w ostatnim czasie często podejmują decyzję o rozpoczęciu nauki języka obcego. Jest to motywowane potrzebą doskonalenia języka w celach zawodowych, samodoskonalenia, dążenia do samorozwoju (zob. E. Stolarczyk-Ambrozik 2005). Rozpoczynający naukę języka obcego bardzo często mają jasne wyobrażenie o tym, dlaczego decydują się na naukę bądź powrót do nauki języka, mają jasno sprecyzowane cele i szczególnie na samym początku - są bardzo zmotywowani i pozytywnie nastawieni do nauki.

W niniejszym artykule poruszona zostanie problematyka nauczania języka rosyjskiego wśród dorosłych uczniów - konsultantów, managerów, dyrektorów finansowych ponownie rozpoczynających naukę języka rosyjskiego w prywatnych firmach. Przedstawiony zostanie profil ucznia, jego potrzeby, cechy charakterystyczne po to, aby wyodrębnić i pokazać kilka zasad efektywnych zajęć w firmie. Zwrócona zostanie uwaga na problemy, z jakimi może zetknąć się nauczyciel języka obcego pracujący z klientem biznesowym, a przede wszystkim na nielingwistyczne składowe jednostki dydaktycznej, 
mające istotny, zdaniem autora, wpływ na lepszą jakość zajęć językowych. Należy zwrócić uwagę na to, jak ważne jest umiejętne motywowanie kursantów, jak istotne są metody, dzięki którym zapamiętywanie nowego materiału przebiega szybciej, a przede wszystkim na ważną rolę umiejętnie wykorzystywanych technik nauczania.

Przed nauczycielami języków obcych, którzy uczą dorosłych, stoją nowe wyzwania. Warto uświadomić sobie, że współczesny lektor, nauczyciel, wykładowca to osoba, która jest współuczestnikiem i współkreującym zajęcia, partnerem w procesie glottodydaktycznym, monitorem postępów. Aby zajęcia były efektywne i efektowne oraz wychodziły naprzeciw oczekiwaniom zainteresowanego, trzeba zwrócić uwage na kilka czynników. Należy przede wszystkim ustalić profil ucznia, wyznaczyć cele nauczania, określić metody szkoleniowe oraz opracować działania szkoleniowe.

Określenie profilu uczestnika kursu jest ważne, ponieważ pomaga doprecyzować cele oraz stworzyć program, który musi być dostosowany do potrzeb uczącego się. Wspólne (w relacji nauczyciel-uczeń) dążenie do realizacji celów ma strategiczne znaczenie i ich określenie powinno odbyć się już na pierwszym spotkaniu. Warto dodać, że osoby dorosłe mają naturalną skłonność do wartościowania umiejętności lub wiedzy i pragną dowiedzieć się, jakie jest jej praktyczne zastosowanie (zob. R. Zemke/S. Zemke 1984). Dlatego szczególnie w momentach zmęczenia i zniecierpliwienia należy na bieżąco przypominać o postawionych sobie na wstępie celach, a po ich osiągnięciu - wyznaczać nowe. To wpływa motywująco na dalszy przebieg nauki. Uczniowie dorośli bardzo często dość nerwowo reagują na zbyt długie teksty, zbyt dużą ilość ćwiczeń gramatyczno-leksykalnych, podkreślając, że nie są w stanie zapamiętać aż tak obszernego materiału, nie przyjmują entuzjastycznie wielowątkowych kursów przeglądowych, znacznie bardziej odpowiadają im zajęcia skupione wokół jednego tematu. Dorośli są dość trudną grupą docelową, ponieważ co prawda na samym początku mają bardzo dużo zapału i chęci do nauki, to jednak po trzech, czterech tygodniach pracy pojawiają się zniecierpliwienie, zniechęcenie, wymawianie się brakiem czasu. Co zatem zrobić, aby podtrzymywać chęć w uczniach do językowego doskonalenia? Jak zwiększyć ich zaangażowanie w zajęcia? Odpowiedź na te pytania nie jest prosta i zależy od wielu składowych. Przede wszystkim należy dobrze dobrać i zastosować odpowiednią metodę.

\section{Wybrane metody nauczania dorosłych}

Należy podkreślić, że nie ma jednej metody nauczania, która byłaby dobra dla danej grupy odbiorców. Dlatego nauczyciel, oprócz licznych kompetencji i umiejętności takich jak umiejętności interakcyjne, pedagogiczne, językowe, dydaktyczne (zob. H. Komorowska 2002: 86-87), powinien wykazywać się zdolnościami elastycznego modyfikowania metod nauczania. Zasygnalizowane poniżej metody nauczania w żadnej mierze nie wyczerpują możliwości, jakie daje nauczycielowi współczesna metodyka, jednak wskazują interesującą alternatywę w dydaktyce języków obcych, mogą stanowić uzupełnienie dla innych metod nauczania.

Jeśli chodzi o nauczanie dorosłych, na uwagę zasługuje naszym zdaniem, oprócz tradycyjnych metod - bezpośredniej, audiolingwalnej czy gramatyczno-tłumaczeniowej, przede wszystkim metoda uczenia się przez działanie (zob. M. Silberman 2004: 158). Polega ona na odgrywaniu ról, grach i symulacjach, obserwacjach, ćwiczeniach 
rozwijających wyobraźnię. Owa metoda pozwala utrzymać odpowiedni rytm zajęć, zachować ich dynamikę. Ciekawą propozycją jest zindywidualizowana metoda komunikacyjna, której autorem i propagatorem jest Aleksy Awdiejew, rozwijająca sprawność mówienia i rozumienia ze słuchu, umiejętność czytania ze zrozumieniem oraz pisania (zob. D. Gałyga 2010: 283-285). Owa metoda pomaga uczniowi odnaleźć się w wirtualnym świecie, rozwija umiejętność wypowiadania się w języku obcym na podstawie autentycznych materiałów internetowych. Interesującym wydaje się model nauczania wykorzystywany przez szkoleniowca Toma Andrewsa, który wprowadza zmiany w relacjach wykładowca-student, proponując układ wykładowca-partner. Wyznaje on zasadę: „Szanuję was i dzielę się z wami swoją najcenniejszą wiedzą, a więc najlepszymi narzędziami, informacjami, ćwiczeniami i technikami jakie znam" (zob. M. Scannel/ J. Cain 2014: 18). Otwartość nauczyciela, przyjazna atmosfera na zajęciach, dobre tempo zajęć oraz odpowiednio dobrana metoda zwiększają prawdopodobieństwo osiągnięcia sukcesu dydaktycznego, sprawnego odbioru przekazywanej wiedzy oraz, co ważne, zadowolenia ucznia.

\section{Kilka uwag przed rozpoczęciem zajęć}

Przed wyborem najlepszej metody dla konkretnego ucznia należy najpierw określić jego profil.

(1) Profil ucznia

Uczeń, z którym pracuję indywidualnie, jest bardzo wymagający. Ze względu na pełnione funkcje kierownicze jest często zabiegany, zmęczony, ma napięty grafik, spieszy się i jego telefon informuje go o przychodzących mailach średnio 5-10 razy w ciągu 60 minut. Oprócz tego normalną praktyką jest odbieranie telefonu i krótkie rozmowy z klientami w czasie trwania zajęć. Jeżeli spojrzeć na umiejętności ucznia, to w większości przypadków zna literki, uczył się wcześniej rosyjskiego, ale nie potrafi mówić. Poza tym od razu zastrzega, że nie lubi gramatyki i że nie będzie odrabiał pracy domowej. Jest niecierpliwy, oczekuje szybkich efektów kształcenia. Z drugiej jednak strony ma ogromne pokłady energii i nawet po bardzo ciężkim dniu pracy w firmie jest w stanie zapamiętywać podczas zajęć trudne konstrukcje i skomplikowane wyrażenia, które natychmiast z sukcesem wykorzystuje w komunikacji z rosyjskojęzycznym partnerem biznesowym.

(2) Określenie celu

Po określeniu profilu ucznia, wysłuchaniu jego oczekiwań należy dostosować program do potrzeb uczącego się. Uczeń i uczący muszą jasno widzieć cel i sukcesywnie dążyć do jego realizacji. Rozmowa przed rozpoczęciem kursu zazwyczaj przebiega w języku ojczystym, sprzyja zapoznaniu się, zbudowaniu pierwszych relacji uczeń-nauczyciel, doprecyzowaniu celów i oczekiwań. Kursanci, z którymi pracuję na co dzień, na pierwszym miejscu stawiają cel komunikacyjny. „Chciałbym porozumiewać się”, „Chciałbym umieć o coś zapytać w hotelu, restauracji, na ulicy”, „Chciałbym umieć dokonać autoprezentacji na oficjalnym spotkaniu biznesowym" - to najczęstsze wypowiedzi moich uczniów, którymi dzielą się ze mną na pierwszym spotkaniu.

(3) Środowisko edukacyjne

Zajęcia odbywają się poza miejscem pracy uczniów. Kilkunastoletnie doświadczenie 
pracy z klientem biznesowym pokazuje, że organizowanie zajęć poza biurem, które kojarzy się jednoznacznie z pracą a nie przyjemnością, jaką jest uczenie się języka, owocuje zwiększeniem koncentracji na zajęciach, wpływa na poprawę jakości nauczania. Uczniowie są bardziej aktywni, rozmowni i mniej zestresowani pracą. Moim małym sukcesem jest to, że niektórzy zupełnie wyłączają telefon na 60 minut.

(4) Techniki

W swojej pracy bardzo często wykorzystuję materiały audiowizualne, prezentacje, slajdy tematyczne systematyzujące wiedzę leksykalną, slajdy gramatyczne pozwalające na przyjemne zapamiętywanie gramatyki. Wszystkie wymienione elementy wpływają na dynamiczny przebieg zajęć, mają nieoceniony i pozytywny wpływ na kształt lekcji. Warto dodać, iż zajęcia są zawsze zwięźle opracowane, oparte zazwyczaj wokół jednego zagadnienia leksykalnego (np. hotel, restauracja, środki transportu).

(5) Cechy lektora

Lektor to przede wszystkim partner w procesie przyswajania wiedzy. Lektor nie poucza, nie krytykuje. Podczas zajęć staram się używać formy „my”, która pozwala budować pozytywne i partnerskie relacje. Razem z moim uczniem tworzymy zespół i zależy nam na osiągnięciu wspólnego celu. Jeżeli uczeń nie zapamiętał danego zagadnienia, nie radzi sobie z problemem gramatycznym, wstrzymuję się od krytycznych komentarzy. Stosuję następujące uwagi: „Jeszcze nie udało nam się opanować materiału”, „Spróbujmy powtórzyć to zagadnienie”, „Pamiętajmy, że ....”, „Uważajmy na formy typu...”. Takie formułowanie uwag sprzyja uczeniu się w przyjaznej atmosferze, gdzie uczeń i uczący są partnerami współkreującymi zajęcia.

\section{Nielingwistyczne składowe jednostki dydaktycznej}

Należy zauważyć, że utrzymanie uwagi ucznia na zajęciach jest niesłychanie ważnym, aczkolwiek trudnym zadaniem. Dzisiejszy uczący się lubi być zaskakiwany, często szybko się nudzi. Dlatego istotnym jest dobry początek zajęć (zob. A. Szafernakier 2015). Należy podkreślić istotę efektywnego wykorzystania początku zajęć, gdzie uwaga ucznia jest maksymalnie skupiona. Nie sprawdzajmy w tym czasie zadania domowego, nie zadawajmy pytań, na które sami nie chcielibyśmy odpowiadać. Zamiast sztampowego zachowania, warto zdecydować się na niestandardowe pytania i prowokować do niebanalnych odpowiedzi. Ponadto należy samemu dzielić się swoimi emocjami i myślami, ponieważ pozwala to podtrzymywać dobre relacje, które z kolei wpływają pozytywnie na chęć wypowiadania się w języku obcym. Schematyczność i przewidywalność lekcji powinny być największymi wrogami lektora. Prowadzą one do znudzenia, zniecierpliwienia, a czasem do frustracji ze strony uczniów. W przypadku pojawienia się powyższych symptomów na zajęciach indywidualnych możemy spodziewać się nagminnego odwoływania zajęć, a nawet rezygnacji z uczestnictwa w nich.

Warto zwrócić uwagę na inne nielingwistyczne składowe jednostki dydaktycznej, a mianowicie na budowanie pozytywnego, przyjaznego klimatu na zajęciach. Nauczyciel powinien być dziś dynamicznym trenerem językowym, elastycznym, umiejętnie modyfikującym ćwiczenia oraz właściwie reagującym na zaistniałe podczas zajęć sytuacje, doceniającym swojego ucznia i jego starania. Czasami nawet idealnie przygotowane za- 
jęcia nie będą udane, jeśli po drodze zgubimy „,czynnik ludzki”. Mamy na myśli stosowanie częstych pochwał, docenianie pracy ucznia. Zauważajmy nawet małe postępy, drobne kroki do przodu na edukacyjnej ścieżce naszych uczniów. Każdy prowadzący zajęcia zastanawia się co zrobić, aby efektywnie uczyć. I każdy ma swój własny sposób, swoją własną metodę, która się sprawdza i daje zadowalające rezultaty. Jednak aby efektywnie uczyć, należy odpowiednio dopasować przekazywaną wiedzę i umiejętności do stylów uczenia się. Jak wiadomo, inaczej materiał przyswajają wzrokowcy, słuchowcy i kinestetycy. Warto wykorzystać aktywne formy uczenia się (zob. M. Urban 2010: 1012) - zaliczamy do nich elementy zabawy, teatru, a także wykorzystywanie rekwizytów, przedmiotów ogólnie dostępnych, ponieważ bodźce oddziałują na tworzenie skojarzeń, które idealnie wpływają na proces zapamiętywania materiału.

Ciekawym wydaje się również stosowanie prowokacji jako metody uruchamiającej myślenie twórcze (zob. R. Fisher 1999: 97-98). Aby twórczo rozwiązać problem, pomocne jest wykorzystanie metafor i analogii. Synektycy ${ }^{1}$ wyróżnili trzy rodzaje metafor: analogie bezpośrednie, osobiste i symboliczne. Metoda skojarzeniowa wydaje się skutecznym narzędziem uruchamiającym myślenie twórcze. Na zajęciach języka rosyjskiego wykorzystuję łączenie na pozór niepowiązanych ze sobą elementów. Uruchamiam liczne skojarzenia, czasem skojarzenia czysto sytuacyjne, na przykład ucząc słowa „krawat” (ros. галстук), najpierw odwołuję się do sformułowania „ubrać się galowo”, pomagając zapamiętać początek słowa, a następnie stukając w stół proszę o słowną rekonstrukcję dźwięku („,stuk”). Propozycja skojarzenia tego typu daje stuprocentową poprawną reprodukcję słowa. Oprócz skojarzeń, wprowadzam obrazowanie wykorzystując mowę ciała, np. pokazuję za pomocą układu palców prawej dłoni literę „,” a następnie lewą dłoń, prosząc o wskazanie po rosyjsku ilości palców lewej dłoni. W ten oto sposób zapoznaję ucznia ze słowem „znowu” (ros. „опять”).

Jedną z ulubionych metod jest rysowanie. Szczególnie często w okresie świątecznym proszę uczniów o graficzne przedstawienie świątecznych skojarzeń. Ćwiczenie wydawać by się mogło nieskomplikowane, ,nielingwistyczne”, aczkolwiek uczniowie widzący na zajęciach kredki i kolorowe flamastry od razu ożywiają się, są zaciekawieni, jaki będzie ciąg dalszy i co my właściwie będziemy robić (przecież to zajęcia językowe, a nie plastyka (!)). Podczas wykonywania tego zadania jest dużo zabawy i radości, dzięki czemu złożenie życzeń po rosyjsku nie stanowi większego problemu. Warto dodać, że pisanie życzeń, na przykład urodzinowych w dniu, kiedy są one obchodzone (np. przeze mnie lub mojego ucznia), jeszcze bardziej motywuje do zapamiętywania typowych dla tego rodzaju świąt konstrukcji. Dużą popularnością cieszą się ćwiczenia pozwalające uruchomić wyobraźnię ucznia. Mam na myśli ćwiczenia w postaci dokończenia historyjki, bądź to obrazkowej, bądź to pisanej oraz poprzez dopisywanie zakończenia zdań.

\footnotetext{
${ }^{1}$ Synektyka jest metodą, która wykorzystuje zdolność i pojemność ludzkiego umysłu do łączenia razem na pozór niepowiązanych ze sobą elementów, co z kolei motywuje umysł do poszukiwania nowych idei i rozwiązań w wybranym przez nas problemie (zob. URL http://mfiles.pl/pl/index.php/Synektyka_Gordona). [Pobrano 28.08.2015].
} 


\section{Postawa lektora kluczem do edukacyjnego sukcesu}

Lekcja języka obcego w audytorium dorosłych to dzisiaj nie tylko przekazywanie wiedzy stricte podręcznikowej, to przede wszystkim praca z kreatywnie skonstruowanymi materiałami dydaktycznymi, to wyakcentowanie indywidualnych możliwości ucznia, a także podkreślenie wagi nielingwistycznych składowych zajęć. Uważam, że kluczem do edukacyjnego sukcesu jest postawa lektora, który:

(6) jest partnerem w procesie nauczania;

(7) jest wyrozumiały, cierpliwy, bo pamięta swoje edukacyjne potyczki;

(8) razem z uczniem tworzy kreatywny zespół;

(9) przypomina o celach, których realizacja jest priorytetem, oraz stale nadzoruje postępy swojego ucznia;

(10) nie krytykuje, nie upomina, nie wypomina braków i błędów;

(11)zadaje dobre, stymulujące pytania, ponieważ dobre pytania to esencja dobrego nauczania, to pomost między nauczaniem a uczeniem się (zob. R. Fisher 1999: 97-98);

(12) rozwija myślenie twórcze, wykorzystuje w pracy różnorodne techniki - skojarzenia, obrazowanie, rysowanie;

(13) nie dystansuje się w stosunku do ucznia, nie boi się samemu uzewnętrznić swoich emocji, aby stworzyć atmosferę otwartości.

\section{Kilka zasad dobrych zajęć}

Na podstawie własnego wieloletniego doświadczenia w pracy z klientem biznesowym pozwolę sobie sformułować i zaproponować kilka zasad dobrych zajęć w firmie.

1. Zajęcia powinny odbywać się w komfortowej, przyjaznej oraz bezstresowej atmosferze, ponieważ stres buduje dystans, a to z kolei powoduje wewnętrzną blokadę mówienia w języku obcym oraz aktywnego zapamiętywania słów i wyrażeń. Stres wpływa demotywująco.

2. W centrum uwagi powinna być osoba ucząca się, która jest aktywnie zaangażowana w proces dydaktyczny. Uczeń powinien być w centrum uwagi nauczyciela.

3. Środowisko edukacyjne powinno budzić pozytywne, przyjemne skojarzenia, zachęcać do nauki. Należy unikać głośnych pomieszczeń, wywołujących poczucie dyskomfortu.

4. Zajęcia powinny być urozmaicone elementami wizualnymi, dzięki którym ułatwiamy proces zapamiętywania słów, fraz i wyrażeń, a także mamy możliwość aktywizować różne kanały percepcyjne ${ }^{2}$.

5. Odpowiednio dobrany materiał dydaktyczny powinien być realizowany tylko i wyłącznie w ramach jednego spotkania, opatrzony komentarzem kulturowym, gramatycznym oraz powtórką niezbędnych słów.

Nie ulega wątpliwości, że nigdy nie jest za późno, aby rozpocząć naukę, dlatego należy dołożyć wszelkich starań, aby ci, którzy podjęli się wyzwania, jakim jest uczenie się języka obcego, z przyjemnością i sukcesem realizowali postawiony sobie cel.

\footnotetext{
${ }^{2}$ Wzbogacenie lekcji elementami wizualnymi zwiększa zapamiętywanie o 14-38\%. Badania poświęcone uczeniu się nowych słów wykazały, że gdy procesowi temu służą środki wizualne, zwiększenie efektywności może sięgnąć nawet do 200\% (zob. M. Silberman 2004: 23).
} 


\section{Bibliografia}

Fisher, R. (1999), Uczymy się jak uczyć. Warszawa, 97-98.

Gałyga, D. (2010), Zindywidualizowana metoda komunikacyjna nauczania języków obcych w ujęciu profesora Aleksego Awdiejewa, (w:) A. Dudek (red.), Idea i komunikacja w języku i kulturze rosyjskiej. Kraków, 283-285.

Komorowska, H. (2002), Metodyka nauczania języków obcych. Warszawa, 86-87.

Scannel, M./ J. Cain (2014), Zbiór niedrogich gier szkoleniowych. Warszawa, 18.

Silberman, M. (2004), Metody aktywizujace w szkoleniach. Kraków, 158.

Stolarczyk-Ambrozik, E. (2005), Dorosty jako uczeń - zmiana spoteczna a szansa uczestnictwa w oświacie, (w:) M. Podgórny (red.), Człowiek na edukacyjnej fali. Współczesne konteksty edukacji dorosłych. Kraków, 39-49.

Szafernakier-Świrko, А. (2015), Хорошее начало полдела откачало или о том, как хорошо начать урок, (w:) Studia Methodologica 40.

Urban, M. (2010), Niekonwencjonalne metody szkoleniowe czyli jak uatrakcyjnić zajęcia. Gdańsk, 10-12.

Zemke, R./ S. Zemke (1984), 30 things We know for Sure About Adult Learning, (w:) „Innovation Abstract" 8/VI. (URL https:/gwplusone.files.wordpress.com/2014/06/30things-we-know-about-adult-learning.pdf). [Pobrano 26.08.2015]. 